\title{
Glycemic Index, Starch, and Protein Digestibility in Tempeh Gembus Cookies
}

\author{
Valentina A. Manullang, ${ }^{1}$ Ayu Rahadiyanti, ${ }^{1,2}$ Syafira N. Pratiwi, ${ }^{1}$ and Diana N. Afifah $\mathbb{D}^{1,2}$ \\ ${ }^{1}$ Department of Nutrition Science, Faculty of Medicine, Universitas Diponegoro, Semarang 50275, Indonesia \\ ${ }^{2}$ Center of Nutrition Research (CENURE), Universitas Diponegoro, Semarang 50275, Indonesia \\ Correspondence should be addressed to Diana N. Afifah; d.nurafifah.dna@fk.undip.ac.id
}

Received 24 August 2019; Revised 23 October 2019; Accepted 26 November 2019; Published 10 January 2020

Academic Editor: Antoni Szumny

Copyright (c) 2020 Valentina A. Manullang et al. This is an open access article distributed under the Creative Commons Attribution License, which permits unrestricted use, distribution, and reproduction in any medium, provided the original work is properly cited.

\begin{abstract}
Diabetes mellitus is directly related to diet and lifestyle. Control of blood glucose levels is needed to reduce the risk of complications, and one way is to choose foods with a low glycemic index. Cookies made from tempeh gembus/tempeh gembus flour are expected to be eaten as a snack and are safe for people with diabetes. The aim of this research was to analyze glycemic index (GI), glycemic load (GL), dietary fiber, in vitro starch, and protein digestibility of cookies with tempeh gembus flour substitution. Completely randomized design research with one primary factor used cookies with variations of $0 \%, 25 \%$, and $50 \%$ tempeh gembus flour substitution. GI was calculated using the Incremental Area Under the Blood Glucose Response Curve (IAUC) method. Dietary fiber concentration analysis was done by enzymatic methods. The starch and protein digestion rates were calculated using the in vitro method. GI, GL, dietary fiber, starch digestion rate, and protein digestion rate data were analyzed with descriptive methods. Cookies with lowest GI $(47.01 \pm 11.08 \%)$ and GL $(6.90 \pm 1.63)$ were found in cookies with $50 \%$ tempeh gembus flour substitution. The highest dietary fiber content $(24.61 \pm 0.41 \%)$, digestibility of starch $(48.07 \pm 0.01 \%)$, and protein $(20.27 \pm 0.43 \%)$ cookies were found in cookies with 50\% tempeh gembus flour substitution. The higher tempeh gembus flour substitution produced low GI and GL while its dietary fiber, in vitro starch, and protein digestibility were highest.
\end{abstract}

\section{Introduction}

Diabetes mellitus (DM) is a group of metabolic disorders characterized by hyperglycemia which is caused by impaired insulin secretion or/and insulin performance disorder. Hyperglycemia is a medical condition when the blood glucose level increases above normal levels [1]. The World Health Organization (WHO) predicted there would be a prevalence increase of DM in Indonesia, from 8.4 million people in 2000 to 14 million people in 2006, and it would increase to around 21.3 million people in 2030, indicating there would be a 2-3 times increase in 2035. The International Diabetes Federation (IDF) similarly predicted that DM in Indonesia would increase from 9.1 million in 2014 to 14.1 million in 2035 [2].

Snacks can help to stabilize blood glucose levels. One of the best strategies of meal schedule adjustment to help control blood glucose levels is choosing food with low glycemic index (GI). Foods with low GI do not increase blood glucose quickly, so their consumption overcomes insulin sensitivity and is useful in blood glucose management [3]. Glycemic load (GL) will give more thorough information about food consumption effects on the blood glucose rate and provide a better estimate of the amount of carbohydrates in food.

Dietary fiber can affect the blood glucose concentration [4]. Foods with high dietary fiber have a high contribution towards low GI level. Fiber will slow down the food movement in the digestive tract and slow down the enzyme activity, so that the digestive process, especially starch will get slowed down and the blood glucose response will be slower. Therefore, the GI rate will be lower [5]. High protein rate will stimulate insulin secretion, so the glucose in blood will not become excessive and will be controlled [6]. Protein 
quality in food is determined by the level of amino acids that have complete sequence, suitable composition for the body's need, and a high protein digestion rate. Low starch digestion rate means lower starch hydrolysis by digestive enzymes in a certain period of time. Therefore, blood glucose level will not increase drastically after the food is digested and metabolized by the body. Foods with the high starch digestion rate will generate high GI levels.

Tempeh gembus is a popular traditional food consumed by low-income citizens. Tempeh gembus is made from tofu dregs and goes through a fermentation process by Rhizopus oligosporus [7]. A previous study showed that tempeh gembus has health benefits including antioxidants [8], antimicrobial activity [9], ability to reduce the inflammatory reaction [10-15], and reduce LDL-C and total cholesterol. Tempeh gembus contains 50\% less energy compared to regular tempeh, 3 times the concentration of dietary fiber, and has complete amino acids composition $[16,17]$.

One way to increase snack variation for diabetics is the utilization of high-fiber, low-glycemic index tempeh gembus in the form of snack products such as crackers (kerupuk) and cookies [18]. Cookies are chosen to be healthy snacks because they can be stored for a long period of time, are easy to carry, and are acceptable to people of all ages and socioeconomic levels.

Snacks for diabetics are not yet readily available in Indonesia, so the authors are interested in researching about foods such as cookies with high-fiber, high-protein, and lowGI ingredients that can be consumed as healthy snacks and are safe for diabetics. This research aimed to know the level of the GI, GL, dietary fiber, starch, and protein digestion rate of tempeh gembus cookies.

\section{Materials and Methods}

Dietary fiber, starch digestion rate, and protein digestion rate were measured in the Laboratorium Chemix, Yogyakarta. GI and GL examinations were performed in the Universitas Diponegoro, Indonesia.

This research used a completely randomized study design with one primary factor. Tempeh gembus flour substitutions that were used were $0 \%, 25 \%$, and $50 \%$. Three repetitions were done for each treatment. The following table contains the cookies' formulation with tempeh gembus flour substitution (Table 1).

The baking process of the cookies started with making the tempeh gembus flour. Tempeh gembus was thinly sliced and dried at $110^{\circ} \mathrm{C}$ in an oven for 30 minutes. Dried tempeh gembus was ground with a blender and then sifted with a sieve. Other ingredients for the cookies are $40 \mathrm{~g}$ margarine, $30 \mathrm{~g}$ skim milk, $20 \mathrm{~g}$ stevia sugar, $0.1 \mathrm{~g}$ baking powder, $10 \mathrm{~g}$ corn starch, and $15 \mathrm{~g}$ egg yolk. Cookies were made by homogenizing margarine and stevia sugar with a mixer, adding egg yolk, then adding the rest of ingredients, and mixing until combined completely.

The data collected from this research are as follows: GI, GL, dietary fiber, starch digestion rate, and protein digestion rate. The Incremental Area Under the Blood Glucose Response Curve (IAUC) method was used for the GI calculation.
TABle 1: Cookies' formulation with tempeh gembus flour substitution.

\begin{tabular}{lccc}
\hline Ingredients & $\begin{array}{c}\text { Formula } P_{0} \\
(\mathrm{~g})\end{array}$ & $\begin{array}{c}\text { Formula } P_{1} \\
(\mathrm{~g})\end{array}$ & $\begin{array}{c}\text { Formula } P_{2} \\
(\mathrm{~g})\end{array}$ \\
\hline Flour & 100 & 75 & 50 \\
Tempeh gembus & - & 25 & 50 \\
flour & 40 & 40 & 40 \\
Margarine & 30 & 30 & 30 \\
Skim milk & 20 & 20 & 20 \\
Stevia sugar & 0.1 & 0.1 & 0.1 \\
Baking powder & 10 & 10 & 10 \\
Corn starch & 15 & 15 & 15 \\
Egg yolk & & &
\end{tabular}

GI testing was carried out on 28 subjects with the following inclusion criteria: man or woman between 18-30 years of age, normal body mass index (BMI) $\left(18.5-22.9 \mathrm{~kg} / \mathrm{m}^{2}\right)$, normal blood glucose concentration when fasting $(70-100 \mathrm{mg} / \mathrm{dl})$, nonsmokers and nondrinkers, no history of DM disease in family history, and completed the informed consent from stating the willingness to be a research subject. Exclusion criteria were as follows: using medicine and supplements during intervention, not present at the sample taking time, and/or sick during intervention. The day before intervention, the subject was required to fast (except water) for 10 hours from 22:00 to 08:00 until the next day. Then, the subject's capillary blood was taken to calculate the blood glucose concentration when fasting. Next, the subject was asked to consume test food (pure glucose) and tempeh gembus flour cookies with the $0 \%, 25 \%$, and $50 \%$ rate that contain 50 grams of available carbohydrate. The blood glucose level was tested every 30 minutes $(30,60,90$, and 120 minutes mark) after consuming the test food every two hours. The GI test was performed using a glucometer from the EasyTouch GCU brand. Dietary fiber rate analysis was carried out with enzymatic methods. The starch and protein digestion rates were measured with in vitro methods.

This research received ethical clearance from the appropriate institutional review board with no. 625/EC/FKUNDIPXI/2018. The collected data were tested descriptively to describe the cookies' glycemic index rate, glycemic load, dietary fiber, starch digestion rate, and protein digestion rate.

\section{Results}

3.1. Subjects' Characteristics. There were 28 female subjects who signed the informed consent form with age range between $18-22$ years old, BMI between $18.5-22.9 \mathrm{~kg} / \mathrm{m}^{2}$, and normal FBI (70-100 mg/dl). Research subjects' characteristics are shown in Table 2.

Table 2 shows that subjects' average age is 20 years with an average BMI of $20.9 \mathrm{~kg} / \mathrm{m}^{2}$ and average FBG of $83.4 \mathrm{mg} /$ dl.

3.2. Cookies' Weight Stipulation per Subject. Food tested for their glycemic index rate was cookies with $P_{0}(0 \%), P_{1}(25 \%)$, and $P_{2}(50 \%)$ tempeh gembus flour substitution while the 
TABLE 2: Research subjects' characteristics.

\begin{tabular}{lcccc}
\hline Characteristic & Average + SD & Min & Max & $P$ \\
\hline Age $($ year $)$ & $20 \pm 1.21$ & 18 & 22 & 0.26 \\
BMI $\left(\mathrm{kg} / \mathrm{m}^{2}\right)$ & $20.9 \pm 1.15$ & 19.1 & 22.6 & 0.06 \\
FBG $(\mathrm{mg} / \mathrm{dl})$ & $83.4 \pm 6.31$ & 74 & 97 & 0.42 \\
\hline
\end{tabular}

BMI: body mass index; SD: standard deviation; significant if $P<0.05$; FBG: fasting blood glucose.

standard food used for comparison was pure glucose. Each food contained $50 \mathrm{~g}$ of available carbohydrate known by the amount of total sugar and starch from the food [19]. The cookies' weights for each subject are $P_{0}(95.45 \mathrm{~g}), P_{1}$ $(89.97 \mathrm{~g})$, and $P_{2}(85.18 \mathrm{~g})$, where each weight has the equivalent of $50 \mathrm{~g}$ carbohydrate. Food with standard pure glucose that was given was $50 \mathrm{~g}$ powder dissolved in $240 \mathrm{ml}$ of water. Cookies' weight stipulation per subject is shown in Table 3.

3.3. Cookies' Glycemic Index (GI). Table 4 shows that the cookies' GI rate with tempeh gembus flour substitution in $P_{0}$ (68.67) falls under medium category while $P_{1}$ and $P_{2}$ tempeh gembus flour substitutions fall under low category. GI rates are shown in Table 4.

3.4. Cookies' Glycemic Load (GL). Table 5 shows that the cookies' GL level with $P_{0}$ (8.99), $P_{1}$ (7.45), and $P_{2}$ (6.90) tempeh gembus flour substitutions fall under the low category. GL rates are shown in Table 5.

3.5. Cookies' Dietary Fiber, Starch Digestion, and Protein Digestion Rate. Based on the dietary fiber test, cookies with tempeh gembus flour substitution that have the highest dietary fiber are cookies with $P_{2}(24.61 \%)$ tempeh gembus flour substitution. Based on the protein digestion rate test, cookies with tempeh gembus flour substitution that have the highest digestion rate are also $P_{2}$ cookies. The results of dietary fiber, starch digestion, and protein digestion rate are shown in Table 6.

\section{Discussion}

Subjects that were used in this research are suitable according to the inclusion criteria. After being tested with ANOVA analysis, age data, BMI, and FBG showed there were no significant differences, so subjects were considered homogeneous. GI testing was performed using pure glucose as standard food and cookies with $0 \%, 25 \%$, and $50 \%$ tempeh gembus flour substitution as test food. All of the foods that were tested are equivalent to $50 \mathrm{~g}$ carbohydrate, determined by the rate of their available carbohydrate.

Glycemic index (GI) is a way to give a picture of the relations between carbohydrates in food with responses in blood glucose levels. Food that has low GI can optimize glycemic control in diabetics by slowing down the carbohydrate absorption [20]. GI is classified in three categories, which are low GI $(<55)$, medium GI $(55-75)$, and high GI $(>70)$. Cookies with $50 \%$ tempeh gembus flour substitution have the lowest GI, which is $47.01 \%$. GI rate results show that the higher the tempeh gembus flour substitution, the lower its GI.

Factors that affect a certain food's GI are dietary fiber, starch digestion rate, fat and protein content, and the preparation [21]. Low GI rate may be caused by tempeh gembus, the main ingredient in this research. Tempeh gembus contains $50 \%$ of the energy level of regular tempeh, has higher protein and fat content, and has 3 times the concentration of dietary fiber [16]. Fiber affects food's GI related with its role as a physical inhibitor in the digestive process. Fiber consumption in sufficient amounts will benefit the blood glucose management [22]. It corresponds with research that stated the increase in dietary fiber consumption is related to better GI control [23].

Protein content in tempeh gembus can also affect the low GI rate. High protein content can stimulate insulin secretion, so the glucose in blood is controlled and does not become excessive. The concentration of protein in food will decrease the amount of glucose that is being taken out from systemic circulation, thereby decreasing the food GI rate [24]. Low-GI food will get digested and turned to glucose gradually, and as a result, the highest peak of blood glucose concentration will be low. This means the increase in glucose rate fluctuation is relatively low. On the contrary, high-GI food will get digested and turned into glucose quickly. Therefore, to control the blood glucose concentration, diabetics are suggested to consume food with low GI [25].

GI gives information about the speed of carbohydrate transformation to blood glucose, but it does not give information about the amount of carbohydrates and the impact that certain foods have on blood glucose level. Glycemic load (GL) can give information about the effect that food consumption has on the elevation of blood glucose level. The purpose of low-GI food consumption is to decrease GL. GL is used to evaluate the effect of carbohydrate consumption with food GI taken into account [21]. Food GL is classified into three categories: low GL $(<10)$, medium GL (11-19), and high GL (>20) [3]. Cookies with 50\% tempeh gembus flour substitution have the lowest GL rate, at $6.90 \%$. The GL rate result shows that the higher the tempeh gembus flour substitution, the lower GI in cookies. This is caused by the low number of available carbohydrates. Food with low GI and GL will produce low blood glucose response after being consumed [26]. This corresponds to the previous study which stated consuming food with low-GI and GL rates causes slow elevation of blood glucose levels [27].

Dietary fiber concentration in cookies with tempeh gembus flour substitution is higher than that in control treatment cookies. Cookies with 50\% tempeh gembus flour substitution have higher dietary fiber, which is $24.61 \%$. Dietary fiber concentration increase is caused by the increasing of tempeh gembus flour substitution. This is supported by the previous study which stated that the low wheat flour percentage in the cookie formula decreases the dietary fiber concentration [28]. The suggested fiber intake for diabetics is $25 \mathrm{~g} /$ day [29]. Fiber concentration in every $P_{2}$ cookies is $6.15 \mathrm{~g}$, obtained from cookies' weight on one portion $(25 \mathrm{~g})$ per $100 \mathrm{~g}$ and then multiplied by the fiber 
TABLE 3: Cookies' weight stipulation per subject.

\begin{tabular}{lcccc}
\hline Treatment & Total sugar (\%) & Starch (\%) & Available carbohydrate* $(\%)$ & Cookies' weight** $(\mathrm{g} / \text { subject })^{*}$ \\
\hline$P_{0}$ & 28.53 & 21.68 & 52.38 & 95.45 \\
$P_{1}$ & 30.17 & 23.09 & 55.57 & 89.97 \\
$P_{2}$ & 32.28 & 24.02 & 58.70 & 85.18 \\
\hline
\end{tabular}

${ }^{*}$ Available carbohydrate $=$ total sugar $+(1.1 \times$ starch $) .{ }^{* *}$ Cookies weight $=50$ and $\mathrm{g} /$ Available Carbohydrate $\times 100$.

TABLE 4: Cookies with tempeh gembus flour substitution's glycemic index.

\begin{tabular}{lcc}
\hline Treatment & Glycemic index (\%) & Category \\
\hline$P_{0}$ & $68.67 \pm 12.28$ & Medium \\
$P_{1}$ & $53.66 \pm 16.55$ & Low \\
$P_{2}$ & $47.01 \pm 11.08$ & Low \\
\hline
\end{tabular}

Category: low GI (<55), medium GI (55-70), and high GI $(>70)$.

TABLE 5: Cookies with tempeh gembus flour substitution's glycemic load.

\begin{tabular}{lccc}
\hline Treatment & Weight per serving $(\mathrm{g})$ & Available carbohydrate per serving* & Glycemic load $^{* * *}$ \\
\hline$P_{0}$ & 25 & 13.10 & $8.99 \pm 1.61$ \\
$P_{1}$ & 25 & 13.89 & $7.45 \pm 2.30$ \\
$P_{2}$ & 25 & 14.68 & $6.90 \pm 1.63$ \\
\hline
\end{tabular}

${ }^{*}$ Available carbohydrate per serving $=$ weight per serving $(\mathrm{g}) / 100$ and $\mathrm{g} \times$ available carbohydrate. ${ }^{* *} \mathrm{GL}=\mathrm{GI} \times$ available carbohydate per serving $/ 100$. ${ }_{* * *}$ Category: low GL $(<10)$, medium GL $(11-19)$, and high GL $(>20)$.

TABLE 6: Cookies with tempeh gembus flour substitution's dietary fiber, starch digestion, and protein digestion rate.

\begin{tabular}{lccc}
\hline Treatment & Dietary fiber (\%, wet weight basis) & Starch digestion rate (\%) & Protein digestion rate (\%) \\
\hline$P_{0}$ & $17.59 \pm 0.21$ & $21.32 \pm 0.3$ & $9.02 \pm 1.12$ \\
$P_{1}$ & $20.12 \pm 0.33$ & $38.2 \pm 0.26$ & $19.22 \pm 0.34$ \\
$P_{2}$ & $24.16 \pm 0.41$ & $48.07 \pm 0.01$ & $20.27 \pm 0.43$ \\
\hline
\end{tabular}

concentration test result. From the counted fiber result, every $P_{2}$ cookies' portion can fulfill about $24.6 \%$ of the fiber needs for a person's body.

Starch digestion is the level of easiness of certain starchy foods to get hydrolyzed by starch enzymes and broken down to simpler units of nutrition. Tempeh gembus flour substitution cookies' starch digestion rate is higher than the control treatment cookies' starch digestion rate. The higher the tempeh gembus flour substitution, the higher the starch digestion rate.

Starch digestibility is determined by several factors, such as amylose and amylopectin, fiber, along with the preparation process [30]. Based on enzymatic hydrolytic mechanism, amylose can be hydrolyzed with one enzyme which is $\alpha$-amylase while amylopectin because of its branching chain will be hydrolyzed by more than one enzyme such as $\alpha$ -amylase and then continued by $\alpha$ (1-6) glucosidase. Amylopectin molecule weight is higher than amylose. Based on this consideration, amylopectin needs more time to get digested than amylose [31]. Products with low amylose are estimated to have higher starch digestion rate [32]. Dietary fiber also affects starch digestibility. Food with high dietary fiber will be more difficult to digest or have low digestion rate. Dietary fiber increases mixed food viscosity in the intestines, so it will slow the enzyme and food (starch) interaction. High-fiber food also increases stomach distention which is related to greater feeling of fullness and less appetite. This will also decrease the nutrition absorption of the food by the body [30].

Starch digestion rate elevation is suspected to come from the preparation process, which is one of the factors that influence starch digestibility. In this research, milling or grinding process was done during the tempeh gembus flour production. The grinding process made the food structure to be smooth, so the food will get digested and absorbed easily. Particle size also affects the starch gelatinization process, where smaller starch particle size will make it more easily digested by enzymes so that starch digestion and absorption is fast. While the starch digestion rate of tempeh gembus flour cookies increased, that digestion rate was still categorized as low and cookies with tempeh gembus flour substitute also had high dietary fiber.

Protein digestibility is a term for digestive enzyme (protease) performance to hydrolyze a protein to amino acids. An easily digestible protein shows that the amount of amino acids that gets absorbed and used by the body is high. The protein digestion rate of cookies with tempeh gembus flour substitute is higher than that of the control treatment cookies. The higher the substitution of tempeh gembus flour, the higher the protein digestion rate. High protein digestion rate means that protein can get well hydrolyzed into amino acids, so the amount of amino acids that can get absorbed and used by the body is high, while the low-protein digestion rate means protein is hard to get hydrolyzed to amino acids 
and that causes a low amount of amino acids to get absorbed and used by the body because most of it will get passed through the body with feces.

The increase in the protein digestion rate is caused by the preparation process. This process can influence products' protein digestion rate. The authors did the drying process two times, when creating the tempeh gembus flour and making the cookies. These drying and baking steps in the preparation process can increase the protein digestion rate because they denature the antinutritional protein (antiprotease).

The drying process also changes the width and length of the protein. The relationship between width and length of the protein with the digestion rate is that the lower the protein size, the wider its surface; therefore, its digestion rate can increase because the protein hydrolysis process by the protease enzyme will be easier. The drying treatment can widen the protein's surface. This happens because the drying process will extract the water from protein and make the protein surface wider than before because the protein particle becomes smaller when going through the drying process, and so the protein digestion rate will be higher [33]. The increase in protein digestion rate means that more protein can get digested by the body. High protein may stimulate insulin secretion through the $\mathrm{G} \beta 5$-RGS protein complex, so the GI can be low [6].

The nutrition content per snack serving is usually $10-15 \%$ of daily calorie intake and can be consumed 2-3 times a day, which means the total calories of snacks for diabetics is $200 \mathrm{kcal}$ in 25 grams of cookies. The carbohydrate intake amount that is recommended for diabetics is 55\% of daily calorie intake, so the amount of daily carbohydrate intake in snacks is 27.5 grams. Based on the results of this research, the available carbohydrate per serving of $P_{2}$ cookies is 14.68 grams; therefore, to fulfill the daily carbohydrate intake for snacks, the amount of $P_{2}$ cookies needed is $46.83 \mathrm{~g}$.

\section{Conclusions}

Cookies that have the lowest GI and GL (47.01\% and 6.90\%) are cookies with $50 \%$ tempeh gembus flour substitute. The higher the tempeh gembus flour substitution, the lower its GI and GL rates. Cookies with 50\% tempeh gembus flour substitute have higher dietary fiber, starch digestion, and protein digestion rates.

The available carbohydrate testing method needs to be performed with more thorough and standardized methods such as the anthrone-sulfuric method while using a UV-visible spectrophotometer instrument to get a more valid test result. The recommended cookies are cookies with 50\% tempeh gembus flour substitute that have lower GI and GL rates.

\section{Data Availability}

The cookies' formulation, subject's characteristics, cookies' weight stipulation per subject, cookies' glycemic index, cookies' glycemic load, and cookies' dietary fiber, starch digestion, and protein digestion rate data used to support the findings of this study are included within the article.

\section{Conflicts of Interest}

The authors declare that they have no conflicts of interest.

\section{References}

[1] American Diabetes Association, "Diagnosis and classification of diabetes mellitus," Diabetes Care, vol. 36, no. 1, pp. 67s-74s, 2013.

[2] I.D. Federation, IDF Diabetes Atlas, Vol. 34, International Diabetes Federation, Brussels, Belgium, 6th edition, 2013.

[3] M. J. Franz, "Medical nutrition therapy for diabetes mellitus and hypoglycemia of nondiabetic origin," in Krause's Food and Nutrition Care Proccess, pp. 675-706, W.B. Saunders Co., Philadelphia, PA, USA, 12 th edition, 2012.

[4] G. Fernandes, A. Velangi, and T. M. S. Wolever, "Glycemic index of potatoes commonly consumed in north America," Journal of the American Dietetic Association, vol. 105, no. 4, pp. 557-562, 2005.

[5] A. B. Arif, A. Budiyanto, and Hoerudin, "Glycemic index of foods and its affecting factors," Jurnal Litbang Pertanian-Kementerian Pertanian, vol. 32, no. 3, pp. 91-99, 2013.

[6] Q. Wang, A. N. Pronin, K. Levay et al., "Regulator of G-protein signaling $\mathrm{G} \beta 5-\mathrm{R} 7$ is a crucial activator of muscarinic M3 receptor-stimulated insulin secretion," The FASEB Journal, vol. 31, no. 11, pp. 4734-4744, 2017.

[7] A. L. Nurdini, L. Nuraida, A. Suwanto, and Suliantari, "Microbial growth dynamics during tempe fermentation in two different home industries," International Food Research Journal, vol. 22, no. 4, pp. 1668-1674, 2015.

[8] R. K. Agustina, F. F. Dieny, N. Rustanti, G. Anjani, and D. N. Afifah, "Antioxidant activity and soluble protein content of tempeh gembus hydrolysate," Hiroshima Journal of Medical Sciences, vol. 67, pp. 1-7, 2018.

[9] A. Noviana, F. Dieny, N. Rustanti, G. Anjani, and D. Afifah, "Antimicrobial activity of tempeh gembus hydrolyzate," IOP Conference Series: Earth and Environmental Science, vol. 116, pp. 1-9, 2018.

[10] D. N. Afifah, M. Sulchan, D. Syah, Yanti, and M. T. Suhartono, "Isolation and identification of fibrinolytic protease-producing microorganisms from Red Oncom and Gembus, Indonesian fermented soybean cakes," Malaysian Journal of Microbiology, vol. 10, no. 4, pp. 273-279, 2014.

[11] D. N. Afifah, M. Sulchan, D. Syah, Y. Yanti, M. T. Suhartono, and J. H. Kim, "Purification and characterization of a fibrinolytic enzyme from Bacillus pumilus 2.g isolated from gembus, an Indonesian fermented food," Preventive Nutrition and Food Science, vol. 19, no. 3, pp. 213-219, 2014.

[12] D. N. Afifah, N. R. Anjani, D. Syah, Yanti, and M. T. Suhartono, "Proteomics study of extracellular fibrinolytic proteases from Bacil-lus licheniformis $\mathrm{RO} 3$ and $\mathrm{Ba}-$ cillus pumilus 2.g isolated from In-donesian fermented food," IOP Conference Series: Earth and Environmental Science, vol. 55, pp. 1-10, 2017.

[13] R. Kurniasari, M. Sulchan, D. Afifah, G. Anjani, and N. Rustanti, "Influence variation of tempe gembus (an Indonesian fermented food) on homocysteine and malondialdehyde of rats fed an atherogenic diet," Romanian Journal of Diabetes Nutrition and Metabolic Diseases, vol. 24, no. 3, pp. 203-211, 2017.

[14] P. K. Dewi, D. N. Afifah, N. Rustanti, M. Sulchan, and G. Anjani, "The effect of tempeh gembus variations to serum levels of high sensitivity C-reactive protein (hsCRP) and serum levels of fibrinogen of sprague dawley rats with 
aterogenic diet," Romanian Journal of Diabetes Nutrition and Metabolic Diseases, vol. 25, no. 1, pp. 91-97, 2018.

[15] D. N. Afifah, N. Nabilah, G. T. Supraba, S. N. Pratiwi, Nuryanto, and M. Sulchan, "The effects of tempeh gembus, an Indonesian fermented food, on lipid profiles in women with hyperlipidemia," Current Nutrition \& Food Science, vol. 16, no. 1, pp. 56-64, 2020.

[16] M. Sulchan and E. Nur, "Nutrional value and amino acid composition of tempe gembus and its effect on growth of rats," Maj Kedokt Indon, vol. 57, no. 3, pp. 80-85, 2017.

[17] R. N. S. Damanik, D. Y. W. Pratiwi, N. Widyastuti, N. Rustanti1, G. Anjani, and D. N. Afifah, "Nutritional composition changes during tempeh gembus processing," IOP Conference Series: Earth and Environmental Science, vol. 116, pp. 1-10, 2018.

[18] D. N. Afifah, G. Nugrahani, V. N. Hastuti, and F. Arifan, "The characteristics of kerupuk gembus," IOP Conference Series: Earth and Environmental Science, vol. 292, pp. 1-9, 2019.

[19] F. Brouns, I. Bjorck, K. N. Frayn et al., "Glycaemic index methodology," Nutrition Research Reviews, vol. 18, no. 1, pp. 145-171, 2005.

[20] T. P. Trinidad, D. H. Valdez, A. S. Loyola et al., "Glycaemic index of different coconut (Cocos nucifera)-flour products in normal and diabetic subjects," British Journal of Nutrition, vol. 90, no. 3, pp. 551-556, 2003.

[21] R. A. Lenner, "Glycaemic Index; Relevance for health, dietary recommendations and food labelling," Scandinavian Journal of Nutrition, vol. 48, no. 2, pp. 84-94, 2004.

[22] C. Chen, Y. Zeng, J. Xu et al., "Therapeutic effects of soluble dietary fiber consumption on type 2 diabetes mellitus," Experimental and Therapeutic Medicine, vol. 12, no. 2, pp. 1232-1242, 2016.

[23] H. Fujii, M. Iwase, T. Ohkuma et al., "Impact of dietary fiber intake on glycemic control, cardiovascular risk factors and chronic kidney disease in Japanese patients with type 2 diabetes mellitus: the Fukuoka Diabetes Registry," Nutrition Journal, vol. 12, no. 1, 2013.

[24] I. P. Sari, E. L. Rumiyati, and I. M. Setiawan, "Glycaemic index of uwi, gadung, and talas which were given on rat," Journal of Traditional and Complementary Medicine, vol. 18, no. 3, pp. 127-131, 2013.

[25] American Diabetes Association, "Evidence-based nutrition principles and recommendations for the treatment and prevention of diabetes and related complications," Diabetes Care, vol. 25, no. 1, pp. 202-212, 2002.

[26] D. J. Jenkins, C. W. Kendall, L. S. Augustin et al., "Glycemic index: overview of implications in health and disease," The American Journal of Clinical Nutrition, vol. 76, no. 1, pp. 266S-273S, 2002.

[27] A. Jafar and R. Indriasari, "Diet and blood sugar levels of type 2 DM patient," J. Media Kesehat. Masy. Indones., pp. 211-218, 2014.

[28] H. Gustiar, Physico-chemical Properties and Glycemic Index of Cookies from Modified Arrowroot (Maranta Arundinacea L.) Starch, Institut Pertanian Bogor, Bogor, Indonesia, 2009.

[29] American Diabetes Association, "Diagnosis and classification of diabetes mellitus," Journal of Diabetes Care, vol. 33, pp. 62-69, 2010.

[30] A. Lovegrove, C. H. Edwards, I. De Noni et al., "Role of polysaccharides in food, digestion, and health," Critical Reviews in Food Science and Nutrition, vol. 57, no. 2, pp. 237253, 2017.

[31] D. L. Nelson and M. M. Cox, "Carbohydrates and glycobiology," in Lehninger Principles of Biochemistry, pp. 248-250,
WH Freeman and Company, New York, NY, USA, 7th edition, 1982.

[32] L.-J. Zhu, Q.-Q. Liu, M.-H. Gu, J. D. Wilson, M.-H. Gu, and Y.-C. Shi, "Digestibility and physicochemical properties of rice (Oryza sativa L.) flours and starches differing in amylose content," Carbohydrate Polymers, vol. 86, no. 4, pp. 1751-1759, 2011.

[33] S. Damodaran, "Amino acids, peptides, and proteins," in Fennema's Food Chemistry, pp. 296-302, CRC Press Taylor and Francis Group, Boca Raton, FL, USA, 4th edition, 2008. 


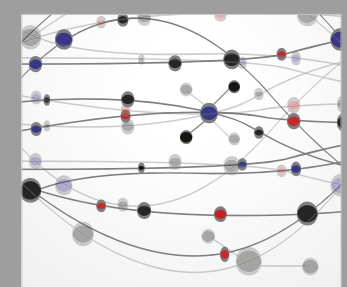

The Scientific World Journal
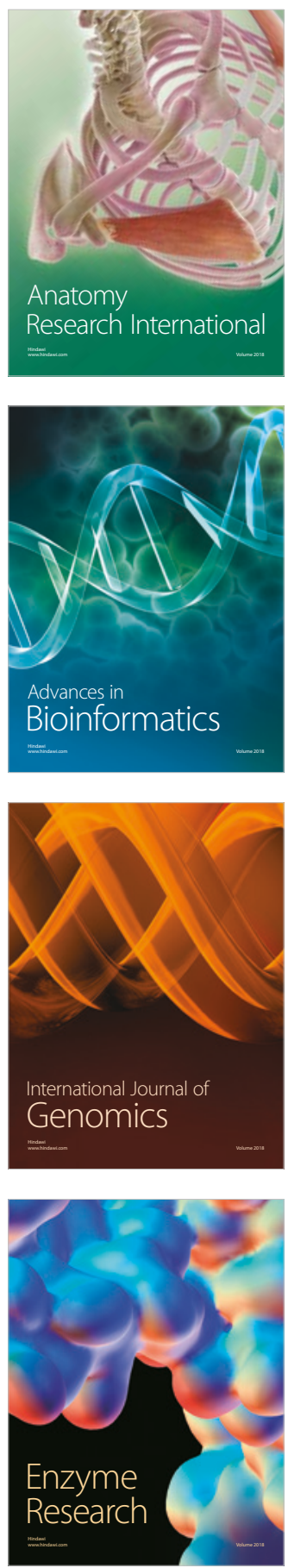
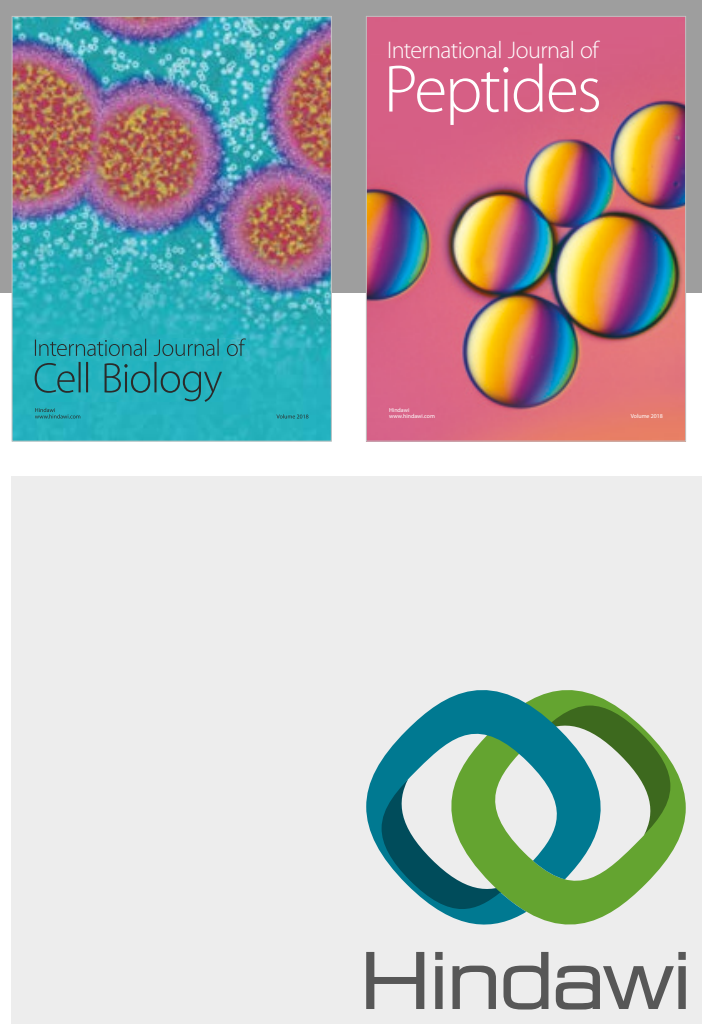

Submit your manuscripts at

www.hindawi.com
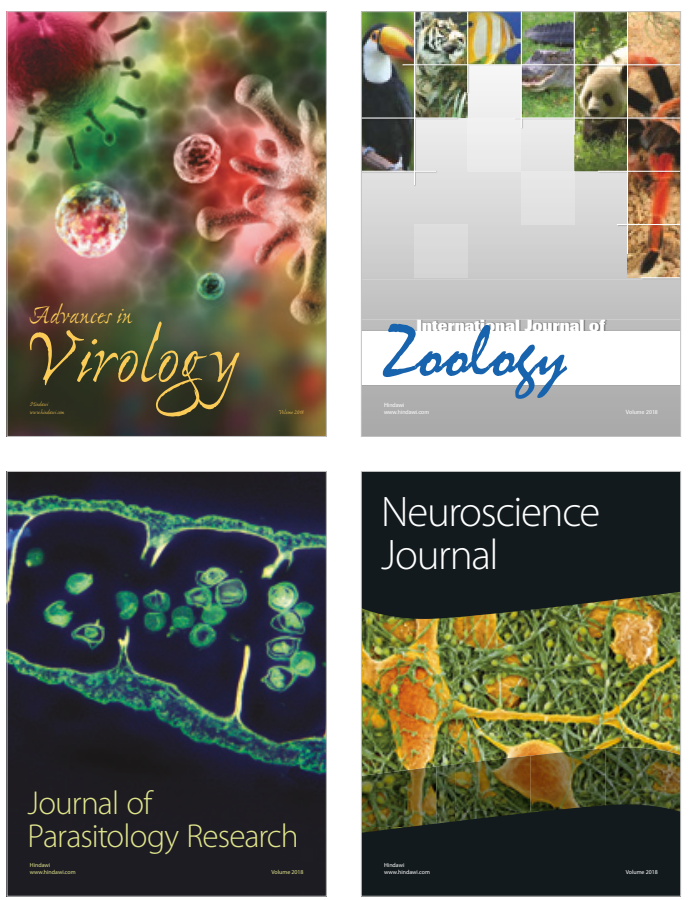
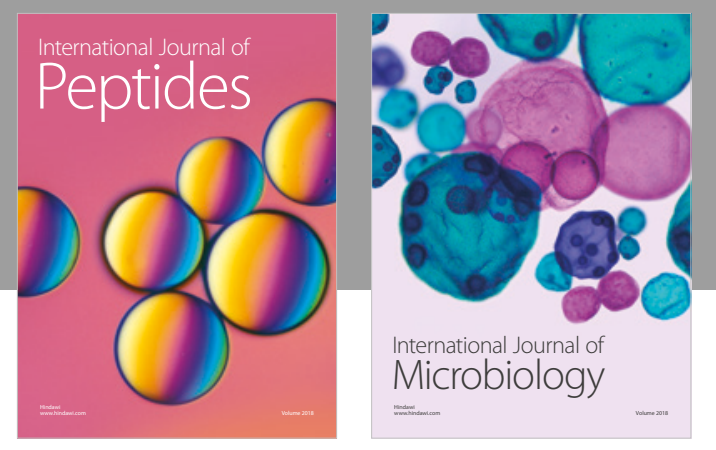

nternational Journal of Microbiology
Journal of
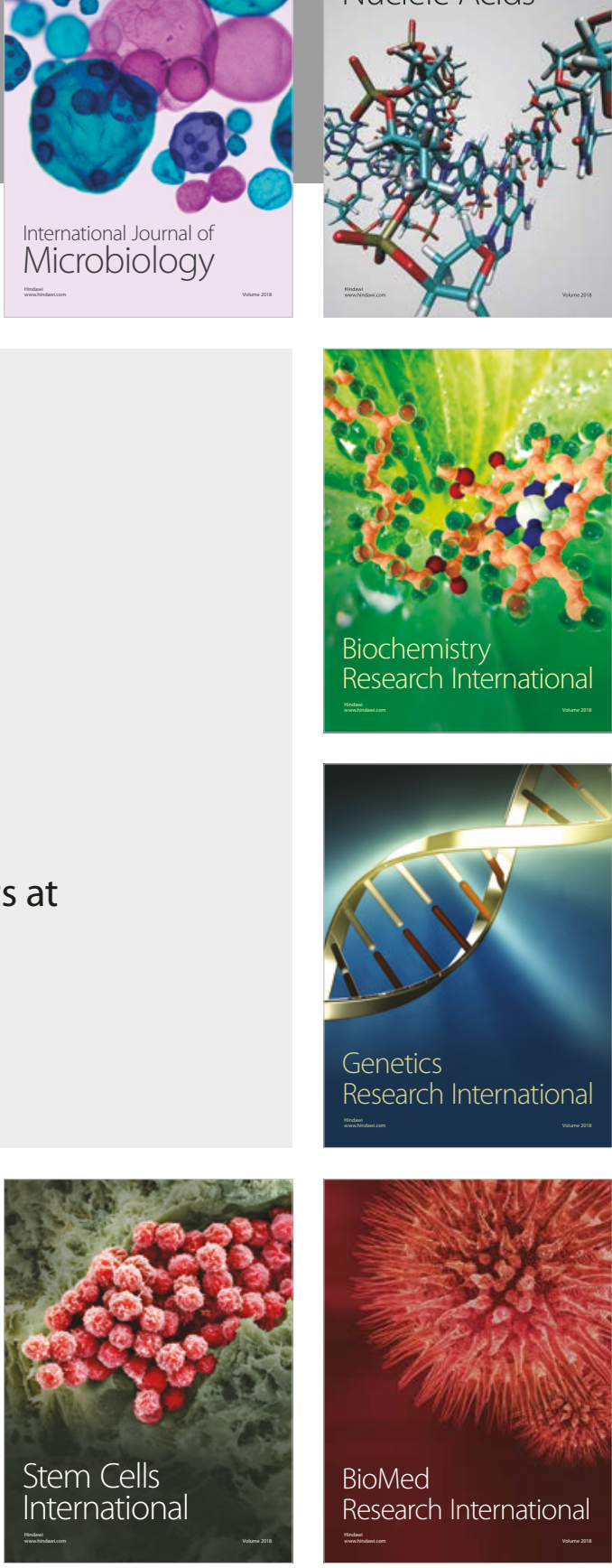
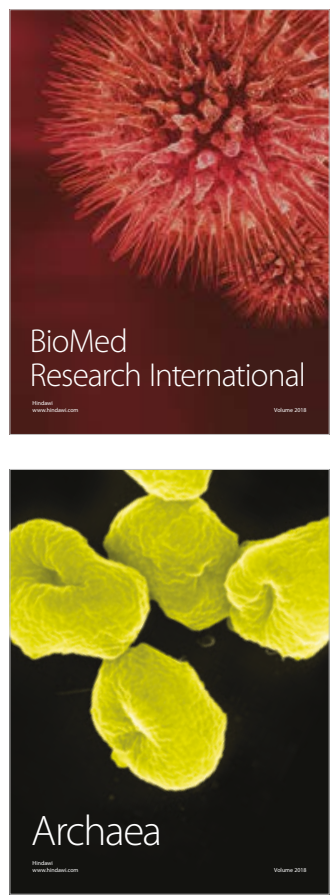